\title{
レーザー内視鏡法による子宮外妊娠の手術
}

\section{Surgical management of tubal pregnancy by means of endoscopic laser}

\author{
武井成夫，小島栄吉，油田啓一，金子慶賛，平川舜，野中博子** \\ Shigeo Takei, Eikichi Kojima, Kei ichi Yuda, \\ Yoshitada Kaneko, Shun Hirakawa, Hiroko Nonaka*
}

東邦大学医学部第一産婦人科学教空 $*^{*}$ 同助教授 $* *$ 東邦大学病理学教窒

First Department of Obstetrics and Gynecology, Toho

University, School of Medicine. * Department of Pathology

\section{Abstract}

In recent years, early detection of ectopic pregnancy has been remarkably improved using ultrasonography, assay of low titer hCG in urine and laparoscopy. We have actively attempted to perform laparoscopy to the patients suspected of ectopic pregnancy for the purpose of detecting as early as possible. We also have introduced YAG laser for hemostasis, adhesiotomy and photovapolization of endometriosis under laparoscopy. In this report, we could manage three ectopic pregnancies which were diagnosed by laparoscopy, radically with YAG laser. Indications for this new procedure will be as follows; 1) The patients who want no more child. 2) Unruptured ectopic tubal pregnancy in good condition. 3) The tumor mass of less than $3-4 \mathrm{~cm}$ in diameter. This new technique have the advantage of incising easily tubal tissue in abloodless condition under laparoscopy and reduced recovery period.

近年レーザー光線の臨床応用が盛んになり, 産 婦人科領域においても，子宫胵部ビランの焼灼， 円錐切除術, 尖形コンジーマの焼枃度亡゙, 主に 外陰部，子宮䐴部疾患に用いられてをた。

著者らは内視鏡下レーザー手術に着目し，止血， 瘾着制離, 子宮内膜症の焼灼，あるいは頸管内腫 瘤の切除奇とを対象に，内視鏡下Y A Gレーザー の臨床応用を検討してをた。

今回, 子官外弤娠 (卵管妊娠) の患者に対し, 腹腔鏡下にレーザー照射による卵管切除術を行い，
良好な成績を得たので紹介する。

一方法一

Y A Gレーザー装は, M B B 社のMedilas を使用した。 Medilasは最大出力が100Wで, 照射時間は 0.1 秒上り9.9秒なで自由に選択可能 である。Y A Gレーザーは，レーザー光の波長が $1.06 \mu \mathrm{m}$ 整かく, ファイバー内者曲的的に導光 でさる特徵をるち，操作性に传れている。また， 他のレーザー光に比較し, 組織深達度が深く, 止 
血効果に儤れていることなどがあげられる。

著者らは，ずY A Gレーザー照射による卵管 切除術の安全性を確認するため，家兔卵管を対象 ハレーザー照射を行ん, 照射量, 組織深達度など を検討する予備奏験を行った。両側の卿管を Y A Gレーザーにて切断後閉腹し， $3 ， 5 ， 7$ 日後， および 2 週間後に再開腹して，その組織像を検討 した。再開腹所見で㤌，いずれの時期です後出血 や強度の癒着翓められなかった。3日目の組織 像のらち，レーザー部灼では，脂肪組織の炭化 変性と血管壁の変性がみられた。レーザー焼灼部 に近々卵管壁平滑筋飞は，核消失や核線状化が中 等度観繁されそれに続く粘膜では，卵管壁の消 失之，上皮の扁平化，变性，脱落肪認められた。 5 日目の組織像では，レーザー焼灼部の変性，壊 死，とくに血管壁の変化は 3 日目より強く，また， foamy cel1 の出現や, 血管内のフィプリン血 栓がみられた。烧灼部近くの卵管では，栈毛唩が 癒合し，間質は著しい浮腫状を呈した。上皮の核 惊状化し，結合織の増生が認められた。7日目 では，レーザー焼灼部に炭化の残存がみられるは 加，著し々血管壁の変性と，炭化物江反広した foreign body giant cell が中等度，また は軽度認められ，焼灼部近くの卵管平滑筋層で壮， 1/2〜2/3 周にわたり核の消失がみられた。 2 週間後では， 1 週間後の組織像と比へ，焼灼部 の壊死亡石灰沈着，多数の foreign body giant cellの出現が注目された。

臨床応用を目的とした症例の選択は，以下のよ 5に行った。腹腔鏡下に即管妊娠の確定診断を必 要とした症例の中で未破裂卵管奼娠であること， すでに生児走得，今後举児を希望し京々症例を対 象とした。乙の適応を满足した被検者には，内視 鏡下に診断汃確定した後，直ちに内視鏡下レーザ 一手術による卵管切除が可能であるとと，本操作 㹥確立された手術法ではなく，内視鏡下手術操作 過程の経過儿より開腹手術を要する症例むあるこ と，をた，術後，後出血等の併発した症例では， やはり開腹手術を要するととを十分に説明し，最 終的にレーザー手術を希望した症例を対象として
選択した。

レーザー照射は，セカンド・パンクチャーとし て牚刺した直往 5 maトラカールより，プローベ に固定したレーザー・ファイバーを楿入し行った。 照射出力 $70 \mathrm{~W}, 1$ 秒間の間歇照射をくり返し, 患側卵管を切除しを。卵管切除後、スコープをオ フセットタイプにかえ，スコープのオペレーティ ングチャンネルより择入した叙子で切除卵管を把 持し，トラカール内人引を入れ腹腔外人とり出し to

一症例-

現在むでのところ3 症例を対象に内視鏡下レー ザー手術を施行し，いずれる良好な手術成績を収 めているので, その各症例につんて, 臨休経過, 内視鏡所見，および手術経過を紹介寸る。 (症例 1 ) 武 $\bigcirc$ 初 $\bigcirc, 22$ 才, 学生, 未婚, $0-\mathrm{G}, 0-\mathbf{P}$ 月経歴: 初経 12 才, 月経周期 29 日型, 順 既往厢：特記すべさとと無し

現病歷：最終月経は昭和 59 年 1 月 17 日上り 5 日間古り以後無月経。2月17日上り始主った外 出血，下腹痛を主訴に 2 月 22 日に来院した。 初猃時所見和上び経過：全身状態恃良好。妊娠反 応恃陰性であった。内猃所見では，子宮壮正常大， 右付属器飞区痛はあるものの腫瘤は触知せず，夕～ グラス曧穿刺にて極く少量の血液を吸引した。そ の後, 経過観察をしていたとてろ, 基礎体温は高 温相が持続し，尿中 h C G b $320 \mathrm{IU} / \ell$ まて陽 性のため，2月 26 日子宮外妊娠の疑いで入院と なった。入院後の超音波断層法では子宦内に胎露 を認めず, 右付属器に一致して腫溜様の像を認め た。をを子宮内容清掃術を行ったとてろ, 内容物 に之しく, 病理学的にも䄉毛加認められず, そこ で子宮外好娠の確定猃断のため, 腹腔鏡検查を計 画した。子宮外妊娠の際には開腹手術となる旨を 患者々説明したところ，開腹手術を強く拒絶され たため, 前述のレーザー手術の内容を十分に説明 した上で，内視鏡下レーザー手術を試みるととと した。腹腔鏡による観察で注，右卵管膨大部に長 
さ約 $2 \mathrm{~cm}$ 腫瘤を認め，その表面は暗赤色を呈し て血管の増生がみられ，妊卵の着休が明らかであ った（図1）。他側の卵管卵褁には異常は認めな かった。本症例では，卵管間膜よりレーザ一照射 を開始し，最後に卵管中枢側にレーザーを照射し て，切除を完了した（図 2，3）。レーザー照射 は $70 \mathrm{~W} 1$ 秒の間歇照射を約 50 回行い, 手術所 要時間は内視鏡に上る観祭も含めて約 60 分であ った。摘出物の断端はところどころ岸化し，卵管 膨大部に長さ約 $2 \mathrm{~cm}$ 腫溜を認めた（図 4 )。 病理組織で，䄉毛組織およびレーザ一照射によ る炭化組織, 間質部の空胞変性を認めた（図 5, 6 )。本症例は術後の後出血, 感染すみられず, 手術後第 10 病日K退院した。

(症例 2 )

吉 $\mathrm{O}$ 嘉 $\mathrm{O}, 32$ 才, 主馐, $3-\mathrm{G}, 2-\mathrm{P}$

月経歴: 初経 12 才, 月経周期 28 日とをに 3 力 月と不順

既往歷：特記すべをとと無し

現病歴：最終月経は昭和 59 年 3 月 10 日上り 5 日間あり，4月 19 日以後外出血および，下腹部 の緊張感があるため 4 月 20 日に来院した。 初猃時所見かよび経過：内診所見では，子宮は正 常大，右付属器に圧痛孝認め，少量の外出血子観 察された。奼娠反応恰泩であり，腹部超音波断

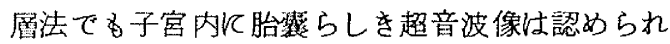
なかったが， 3 週間以上基礎体温の高温相が持続 しており，子宮外妊娠の可能性もあり，精查のた め入院させた。入院時尿中 h C G は $640 \mathrm{IU} / \ell$

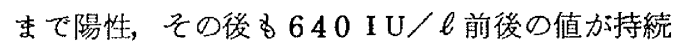
L，基整体温も高温相が持続した。第 9 病日，子 宮内容物の自然排出があった，との訴えがあり， 子宮内容清掃術を施行した。子宮内容物は少量て あり，肉眼的に絨毛は認められず，また，病理検 查に心らてる䋐毛は確認されなかった。第 22 病 日，尿中 h C G 注 $1280 \mathrm{IU} / \ell$ 陽性と上昇傾向 を認め，基礎体温も下降する様子がみられなか。 た。第 27 病日に㤌右下腹部の率引感子出現し, 子宮外妊娠の確定診断を目的として腹腔鏡検查を 施行した。右卵管彭大部には母指頭大の腫瘤を認
め，卵管先端には疑血塊がみられ，右卵管膨大部 奼娠の流産と猃断された(図7)。他側の卵管巣 Kは，異常を認めなかった。本症例も前症例と同 様に，卵管間膜よりレーザー照射を開始し，最後 に卵管自体にレーザーを照射し切除を完了した。

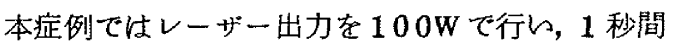
間歇照射 46 回，所要時間 50 分で手術を終了し

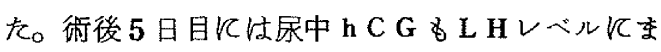
で下降し，徒後 12 病日に退院させた。

(症例 3 )

岡 $\bigcirc$ 完 $\mathrm{O}, 36$ 才, 主婦, $2-\mathrm{G}, 1-\mathrm{P}$

月経歴: 初経 13 才, 月経周期 30 日型, 4 力月 前をでは順調であった。

既往歷：15才腎需督炎

現病歷: 最終月経怊和 59 年 4 月 7 日より 6 日 間古り，6月 7 日《少量の外出血を認めた。6 月 11 日，急に下腹部痛が出現し，しばらく様子を みていたが軽快しないため6月 12 日来院した。 初診時所見および経過：全身状態注良好。弤娠反 応は陰性であった。内詮所見では，子宮はやや腫 大し軟, 右付属器に軽度の压痛を認めたが腫瘤は 触知しなかった。ダグラス窩穿刺で約 $5 m \ell の$ 血液 か吸引され，尿中 h C G は $320 \mathrm{IU} / \ell$ 陽性, 超 音波断層法で子宮内に胎露を認めず，精査のため 直ちに入院させた。念のため全面掻爬を行ったが， 䄉毛は確認されなかった。尿中 h C G 值および入 院後記録させた基䂢体温高温持続の結果上り生活 䄉毛の存在が否定できず，子宮外妊娠の疑いが強 くなってををため，腹腔鏡検査による確定詅断の 必要を決定した。検査に先立ち, 腹腔鏡検査の結 果, 卵管奷娠末破裂が診断された場合は, 引き続 き内視鏡下レーザー手術による卵管切除が可能で あることを説明したとてろ, 患者も本法を強く希 望したため，本法施行の適底を满足している症例 であるととも勘案し，レーザー手術の準備も調え， 腹胵鏡検查を施行した。腹腔鏡所見では，右卵管 膨大部々超小指頭大の腫瘤と約 $35 \mathrm{~m} \ell$ の腹腔内出 血を認め, 右卵管膨大部妊娠 (未破裂) と診断し た(図8)。他側の卵管卵巣には異常を認めなか ったので，直ちにレーザー手術による患側卵管切 
除操作に移った。レーザー照射は $70 \mathrm{~W} 1$ 秒間間 歇照射を 50 回行い，手術所要時間は内視鏡に上 る䚁察を含的 1 時間であった。切除方法壮前 2 例と同様であった。本症例では，尿中 h C Gは術 後10日目KL H レベルKをで降し，術後第15 病日に退院を許可した。

\section{一考察-}

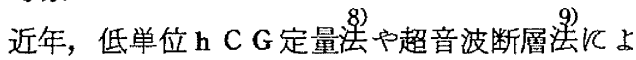
り，子宫外妊娠の早期診断率が向上してをた。し かし，てれらの補助猃断法を㪙使してるなお確定 診断の困難な非定型的未破裂外妊例多く, 内視 鏡検查に上り初好て確定診断が下されるととが少 なくない。山本らは，腹腔鏡検査の導入に上り， 未破裂卵管妊娠の発見率が $5.9 \%$ 上り $30 \%$ に增 加したと報告しており，教室の成績でる，子宮外 弤娠を疑って内視鏡検查を行った 19 例中 14 例 （７３.7\%）が末破裂の卵管妊娠であった。これ らの成績上り，とくに診断困難古外妊症例飞的い て内視鏡検查の有用性が確認されている。

未破裂の卵管妊娠患部は，1.卵管着床部の不規 則な膨隆，2.その表面壮鮮紅色上り暗赤色を呈す， 3.血管加増生, 怒張する, などに代表される所見 が特徵的で，内視鏡猃断のポイントとなる。

子宮外妊娠，とくに卵管妊娠の手術法に壮患部 巣摘除に上る根治療法と，卵管機能の保持を目的 とした保存療法がある。乙れらの手術法の適応と 選択には歷史的背景があり，最近では，マイクロ サーシェリーをどを用いを保存的手術法が增加の 傾向をとりつつまる。

現在のとてろ，諸家の報告をみでる対側卵管が 健常である場合，患側卵管の切除術と保存手術を 行っ大術後妊娠率杜 $30 \sim 40 \%$ と大差南く,方，術後反復外妊率 $10 \%$ 前後之有意差加交认。 患側卵管を保存するか切除するか忙, 術者, 患者 にとってその予後の観点からさわめて重要な課題 であるが，いずれの術式を選択するかについては， case by case 飞検討するというととで, 明確 な結論は出されていない。患側卵管の切除を支持 する考え方の基本怯，術後保存卵管の反復外妊を
憂慮するととにある。一方，患側卵管の保存を支 持する考え方の背景には，実際に他側卵管の健常 性を十分に検査するととが不可能なとと，また， 将来において健側卵管の機能が失われない保証の ないてとなどより，反復外妊の危険性を覚悟して る卵管を保存しようとするすのである。

そてで著者らは，現在の外妊手術に対する考え 方の背礐を踏えて，内視鏡下レーザー手術の適応 を次の上うな対象症例に絞っている。1)すでに 希望する数の生児を得，将来挙児を希望しない症 例，2）全身状態の上々卵管未破裂例，3）内視 鏡所見で腫瘤が $3 \sim 4 \mathrm{~cm}$ 以下の症例(てれ以上の 腫留が形成されていると術中破裂したり，切除 組織の腹腔外搬出が困難となるため)。ただし， 以上の条件を满足していても，癒着などに上りォ リエンテーションの困難な症例や，患部より出血 が多く認められる症例に対しては，内視鏡下レー ザー手術を強行するととなく，開腹手術に的だ政 るととは言うなですない。

著者らは 12 例の家鬼を対象とした照射実験に 上り, 術後 2 週間主での観察期間内に 1 例の後出 血子認めていない。しかし，卵管断端部壊死組織 の剥離，断端部組織の感染などに伴う術後出血の 可能性につんては, 常に念頭に置いて術後管理を 行うことが肝要である。

子宮外妊娠の内視鏡下手術の報告をみると， Decherney, Bruhat，岩田らは腹腔鏡下飞電 気メスを使用しを病果部の切開術，お上び圧出術 後の䋐毛や血液をど内容組織の吸引手術を施行し ている。今回の著者らの手術方法は, Y A Gレー ザーを使用し，乙れらの内視鏡手術をさらに拡大 したすのといえるが，その特長は，卵管の切除を 可能としたとと，交た，切除部位からの出血が全 く無いとと，例数は少ないか，術後，切除断端部 からの後出血を経験していないてとなどが挙げら れる。今回著者らの設定した手術適応条件を遵守 するととにょり，卵管切除の術式は容易であると とが確認された。今後の課題は, 症例を重祇ると とにょり, 術式の確立ととるに, 後出血なとの術 後合併症の発生頻度を検討し, 術後, 入院に上る 
管理期間の每縮を図るととなどである。

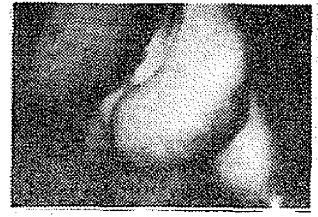

図 1. 右卵管膨大部妊 娠患部の腹腔鏡所 見

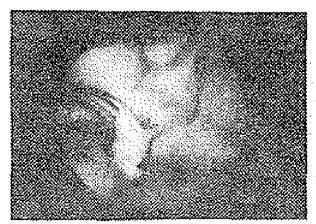

図 3. 切除後の断端

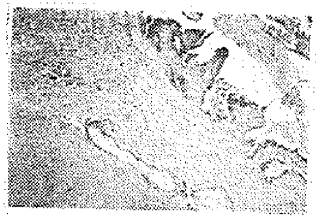

図5.内部に絾毛組織 を認める。

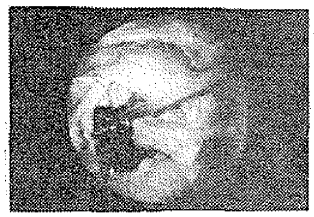

図 7. 症例 2 の腹腔鏡 所見

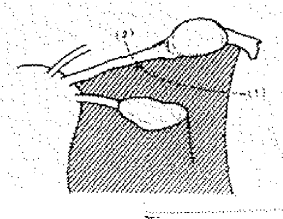

図 2. 卵管切除の方法 (後方占り)

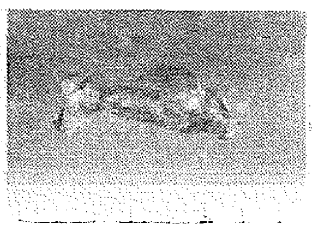

図 4. 摘出物, 約 $2 \mathrm{~cm}$ の腫瘤を認める。

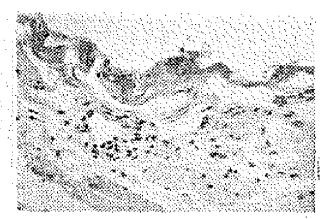

図 6. 表面には炭化組 織, 下層《は空胞 変性が認められる。

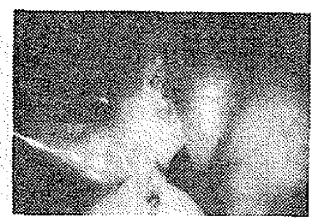

図 8. 症例 3 の腹腔鏡 所見。切除完了直 前の状態を示す。
文 献

1）新井正夫ほか：Y A Gレーザーを用いた子宮 頸部病変の治療。産婦治療, 45:657,

\section{2.}

2）関本昭治： $\mathrm{CO}_{2}$ レーザーの我が領域の適応症。
座と挶，51:65，1984.

3) 塚本直樹：婦人科領域にむけるレーザーの応 用。医学のあゆ夕，124：544，1983.

4）小島栄吉洷か：婦人科突患の内視鏡下レーザ 一手術。産婦治療，49：496，1984.

5）小島栄吉洷か：YA Gレーザーによる子宮内 膜症の内視鏡的治療。第 5 回エンドメトリオー シス研究会講演集, 81,1984 ,

6）小島栄吉汪か：Y A Gレーザーによる子宮頸 部有茎腫瘤の切除。産妒治療, $49: 647$, 1984 .

7) 小島栄吉任加: Excision of broadbased cervical polyp by YAG laser. 日本レーザ一医学会誌，4：119，1984.

8) M. Seppala, et.al. : Improvement diagnosis of pregnancy-related gynaecological emergencies by rapid human chorionic gonadtrophin betasubunit assay. Br J Obstet Gynaecol, $88: 138,1981$.

9) Marie T.Kelly, et. al. : The value of sonography in suspected ectopic pregnancy. Obstet Gynecol, 53 : $703,1979$.

10)山本浩汪か：卵管一ことに子宮外妊娠の保存 手術一。産と婦， $44: 249,1977$.

11)古川隆正祦：子宮外妊娠の臨床統計一内視 鏡施行例を中心として一。日産妇東京地方部会 誌, $33: 152,1984$.

12) Dan Sherman, et. a l. : I mproved fertility following ectopic pregnancy. Fertil Steril, $37: 497,1982$.

13) Alvin M. Siegler : Replacement, repair, and removal of fallopian tubes. JAMA, $37: 611,1982$.

14) S. Timonen, et. al.: Tubal pregnancy, choice of operative method of treatment. Acta Obstet Gynecol $\mathrm{Sc}$ and , $46: 327,1967$.

15) Alan Decherney, et. al. : The 
conservative surgical management of unruptured ectopic pregnancy.

Obstet Gynecol, $54: 451,1979$.

16) A l an Decherney, et. al : Surgical management of unruptured ectopic pregnancy. Fertil Steril, $35: 21$, 1981.

17) Maurice Bruhat, et. al.: Treatment of ectopic pregnancy by means of laparoscopy. Fertil Steril, 33:411, 1980.

18）岩田嘉行传か：子宮外妊娠の保存手術。座挶 治療, $44: 275,1982$. 